\title{
MULTIPLE PARAMETRIC APPROACHES TO ASSESS ACUTE RADIATION LUNG INJURY OF RATS
}

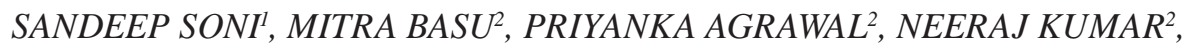 \\ ASEEM BHATNAGAR ${ }^{2}$, NEELAM CHHILLAR ${ }^{1}$ \\ ${ }^{1}$ Institute of Human Behaviour and Allied Sciences, Dilshad Garden, India; \\ e-mail: nlmchhillar@yahoo.co.in; \\ ${ }^{2}$ Institute of Nuclear Medicine and Allied Sciences (INMAS), Defence Research \\ \& Development Organization (DRDO), Delhi, India
}

The effect of whole body gamma irradiation (WBI) in single fraction was studied, as well as its influence on the secretion of various biochemical markers and cellular component that could be used as acute radiation lung injury marker. Sprague dawley rats were treated with WBI $\left({ }^{60} \mathrm{Co}\right)$ of radiation dose from $1 \mathrm{~Gy}$ to $5 \mathrm{~Gy}$ (dose rate - $0.95 \mathrm{~Gy} / \mathrm{min}$ ). Bronchoalveolar lavage fluid was retrieved from all animals in control and radiation treated groups up to $72 \mathrm{~h}$ post radiation. Bronchoalveolar lavage fluid (BALF) was analyzed for lactate dehydrogenase (LDH), acid phosphatase (AP), alkaline phosphatase (ALP), cell count and total protein. Intragroup and intergroup comparison of BALF parameters at different radiation doses showed significant difference. LDH was significantly increased as the dose increased from $1 G y$ to $5 G y(P=0.00)$ after $2 \mathrm{~h}$ with effect size of difference $(r>0.3)$. ALP was significantly altered after $3 G y$ and $4 G y(P<0.05)$. AP was significantly altered at 2Gy-5Gy $(P<0.05)$. Total protein level changed significantly from $1 G y$ to $5 G y(P<0.00)$. Cellular content of BALF showed significant changes after radiation exposure. BALF parameters like LDH, AP, ALP, neutrophils, lymphocytes, total leukocyte count and total protein were sensitive to radiation exposure and their levels vary significantly up to $72 \mathrm{~h}$ after single whole body radiation exposure in Sprague dawley rats. It can be concluded that the biochemical indices in BALF have more wide application in evaluation of acute radiation induced lung injury.

Ke y word s: acute radiation lung injury, bronchoalveolar lavage fluid (BALF), biochemical indices.

$\mathrm{R}$ adiological events are of infrequent incidence, but have the high potential of creating a disastrous situation, such as nuclear accidents of Chernobyl and Fukushima. There is increasing risk for the unplanned exposure of individuals to ionizing radiation from nuclear accidents, malicious act of terrorism and occupational exposures. For better prepared planning for the medical management of radiation exposed victims, it is necessary to estimate the dose received by exposed victims [1]. Determination of dose distribution from physical nature of radiological event does not produce accurate dose for individuals [2]. There are so many factors, which create difficulties in accurate individual dose estimation. Therefore, there is a need to develop dosimetry method which can rapidly estimate individual radiation exposure dose. A single parameter based technique is not sufficient to assess acute radiation exposure at the time of nuclear and radiological event. Effective triage and treatment will require a multi parameter based approach for radiation biodosimetry [3].

The lung is one of the most radiosensitive organs of the body [4]. The radio-sensitivity of the lung makes it vulnerable to radiation exposure. The lung is able to tolerate high dose in a small volume, but is less able to tolerate a low dose to the whole lung [5]. Biochemical, subcellular and cellular damage due to absorption of ionizing radiation is well established [6]. Radiation induced lung injury begins within hours after radiation exposure but clinical feature and other features start appearing within weeks to months after exposure [7]. The radiation induced lung injury can be assessed by analyzing bronchoalveolar lavage fluid (BALF). BALF is a sampling of the lower respiratory tract by the instillation and subsequent aspiration of fluid [8]. Biochemical changes in BALF are useful to detect pulmonary injury [9]. The technique recover cells, proteins, lipids, and other chemical components from the epithelial surface 
of the lungs. As a research specimen, it is useful for the examination of the cellular and humoral events occurring in the lungs, and has supported in advancing hypothesis regarding disease pathogenesis. The cells recovered from BALF are much more heterogeneous than the cells acquired from blood [10]. Increased activity of lactate dehydrogenase (LDH) and alkaline phosphatase (ALP) reflects lung parenchymal cell damage/cell death. Lung parenchymal cells and/or local inflammatory cells, including alveolar macrophages (AM) and polymorphonuclear leukocytes (PMN) may be potential source of LDH in BALF. The ALP activity in BALF has been associated with pneumocyte type II cell damage [11].

In the present study, BALF was taken as test sample. Although many studies have reported the effect of gamma radiation on BALF parameters, there is no wide literature available which shows the periodic study of the BALF parameters as early screening biomarkers of acute radiation injury. The aim of the present study was to observe the effect of whole body radiation on BALF parameters.

\section{Materials and Methods}

Animals. The animal study protocol was approved by the institutional Animal Ethics committee, Delhi (INDIA) and the research adhered to the "Principles of Laboratory Animal Care" [12]. Male Sprague dawley rats (8-9 week old; approx 200-250 g body weight) were obtained from animal house. Rats were given free access to standard laboratory animal feed (Hindustan Lever Ltd., Bombay, India) and water ad libitum. The temperature of the animal room was kept at $22{ }^{\circ} \mathrm{C}\left( \pm 3{ }^{\circ} \mathrm{C}\right)$ and relative humidity at $30-70 \%$ throughout the experiment. The rats were housed in polypropylene plastic cages. Rats were divided randomly into 5 groups according to radiation dose 1Gy to 5Gy. Four time points were selected for the study: T2 ( $2 \mathrm{~h}$ post irradiation), T24 (24 h post irradiation), T48 (48 h post irradiation) and T72 (72 h post irradiation) ( $n=6$ at each time point). Six rats were included as control (T0) for the study $(n=6)$.

Radiation exposure to animals. The animals were anesthetized with intravenous (I.V.) injection of $0.1 \mathrm{ml}$ diazepam $(10 \mathrm{mg} / \mathrm{ml})$ prior to radiation treatment. The anaesthetized rats were placed in plastic cages during exposure. Rats were then irradiated with a single dose of 1Gy-5Gy whole body irradiation (WBI) by 60Cobalt teletherapy unit (Bhabhatron II, Panacea Med. Tech. Pvt. Ltd., Bangalore, India), at dose rate of $0.95 \mathrm{~Gy} / \mathrm{min}$ with a focus to skin distance of $120 \mathrm{~cm}$. The total radiation field, in which rats were irradiated, was $20 \times 20 \mathrm{~cm}$. Control animals were treated with sham irradiation. All experiments were carried out according to institutional guidelines for the care and use of laboratory animals.

Lung lavage harvesting. Animals were humanly sacrificed at $2,24,48$, and $72 \mathrm{~h}$ post radiation exposure and BALF was recovered from animals after tracheostomy and intubation with a 20-gauge luer stub adapter (Becton Dickinson, Sparks, MD). The lungs were gently lavaged twice with sterile $50 \mathrm{mM}$ PBS (pH 7.2) [13]. For the measurement of cell count, BALF was filtered through sterile gauze for the removal of mucous and debris. Cell count in BALF was performed with a hemato-cytometer chamber (Neubauer) [14]. The BALF samples were immediately immersed in ice flakes and centrifuged at $500 \mathrm{~g}$ for $5 \mathrm{~min}$ at $4{ }^{\circ} \mathrm{C}$. The supernatant was kept frozen at $-80^{\circ} \mathrm{C}$ until analysis. Within the acellular supernatant of BALF, the following biochemical indices were assessed: alkaline phosphatase (ALP), to assess the degree of pneumocyte type II activity; activity of acid phosphatase (AP), to detect the release of enzyme from activated or lysed phagocytes; activity of cytosolic enzyme, lactate dehydrogenase (LDH), to detect general toxicity and total protein.

The alkaline phosphatase (EC 3.1.3.1) was determined by colorimetric enzymatic method with commercially available kit (Biovision, USA). P-nitrophenyl phosphate (pNPP) was used as a phosphatase substrate. Substrate produces yellow colour when dephosphorylated by ALP and measured at $405 \mathrm{~nm}$.

The acid phosphatase (EC 3.1.3.2) was determined by fluorometric enzymatic method with commercially available kit (Biovision, USA). Non-fluorescent methylumbelliferyl phosphate disodium (MUP) was used as substrate, which has $\mathrm{Ex} / \mathrm{Em}=360 / 440 \mathrm{~nm}$ when dephosphorylated by Acid phosphatase.

The lactate dehydrogenase (EC 1.1.1.27) was determined by colorimetric enzymatic method with commercially available kit (Sigma-aldrich, USA). In this colorimetric assay, NAD was reduced to NADH by $\mathrm{LDH}$, which then interacted with specific probe and produced colour (measured at $450 \mathrm{~nm}$ ). The kit can detect $1-100 \mathrm{mU} / \mathrm{ml}$ of $\mathrm{LDH}$. One unit of $\mathrm{LDH}$ is the amount of enzyme that catalyzes the conversion of lactate to pyruvate to generate $1.0 \mu \mathrm{mol}$ to NADH per min at $37^{\circ} \mathrm{C}$. 
Total protein level was determined with a micro-bicinchoninic acid (BCA) protein assay kit (Pierce, Rockford, IL).

The data was analyzed using SPSS for windows (version 20.0; SPSS Inc., Chicago). As the data was not normally distributed, median and range were taken as means of central tendency and means of dispersion respectively to describe the data. Intragroup temporal comparison of various parameters was done using non-parametric Friedman test. $P$ value less than 0.05 was taken as significant. Post hoc comparison of significant results was done using Wilcoxon signed-rank test. Intergroup comparison was done using Kruskal Wallis test followed by Mann-Whitney test for post hoc comparison. Effect size of the significant differences was calculated using ' $r$ ' value. Effect size was calculated as follows; $r$ value $<0.3$ was taken as small effect size, $r$ value between 0.3-0.5 was taken as medium effect size and large effect was considered when $r$ value $>0.5$.

\section{Results and Discussion}

The amount of retrieved BALF was 2.0-2.5 ml for each time point. The cellular profile, ALP, LDH and AP activities in BALF samples of irradiated and control samples were examined and summarized.

It was revealed that a statistically significant change in LDH level was observed in the animals at the radiation dose from 1Gy to 5Gy $(P<0.05)$. Post hoc comparison showed a medium effect size $(r=0.3-0.5)$ in 1Gy-5Gy groups at 2, 24 and $48 \mathrm{~h}$ post radiation exposure while small effect size at $72 \mathrm{~h}(r<0.3)$. LDH level was significantly increased in the animals of 3Gy-5Gy group up to $2 \mathrm{~h}$ post radiation exposure $(P>0.001)$, while afterwards it started declining $(P>0.05)$. Same trend was also monitored in radiation group 4Gy and 5Gy throughout the experiment. It was observed that there was a significant change in LDH concentration in BALF at different radiation doses which was confirmed by post hoc analysis.

A significant difference in ALP level in 1Gy5 Gy radiation group with medium to high effect size $(P<0.05, r=0.3-0.6)$ was observed. Post hoc test revealed statistically significant change at $24 \mathrm{~h}$ $(P=0.001, r=0.373)$ in 1 Gy-5Gy irradiated group. The difference of median values was significant $(P<0.05)$ at $48 \mathrm{~h}$ post radiation exposure in all radiation groups which was confirmed by post hoc analysis. The effect of different radiation dose at particular time point is also shown in Fig. 1.
We also found that AP level in 1Gy-5Gy radiation group significantly altered $(P>0.05)$. It was revealed that a significant change in 2 Gy radiation group was observed at $24 \mathrm{~h}$ post radiation exposure $(P=0.041, r=0.349)$. Almost similar trend was observed in 3Gy radiation group ( $P=0.026, r=0.375)$. Significant differences were observed in $4 \mathrm{~Gy}$ and 5 Gy radiation groups. Post hoc test revealed significant change at 24 and $48 \mathrm{~h}$ with $P$ value $0.002,0.004$ respectively ( $r$ value $=0.481,0.441)$. It is clear that significant difference between $1 \mathrm{~Gy}$ to $5 \mathrm{~Gy}$ radiation doses was observed after 24 to $72 \mathrm{~h}$ exposure. At $2 \mathrm{~h}$ radiation exposure difference was found nonsignificant which was confirmed and analyzed by post hoc test.

A significant change in total protein was observed in 1 Gy-5Gy radiation group $(P=0.004-0.000)$. Post hoc test revealed no significant difference at 1 Gy radiation dose observed at $2 \mathrm{~h}(P>0.05)$, while at 24, 48 and $72 \mathrm{~h}$ significant difference observed $(P=0.002, r=0.481)$. While in $2 \mathrm{~Gy}$ and $3 \mathrm{~Gy}$ radiation groups significant differences were observed at all time points $(P=0.002, r=0.481)$. Significant differences at all time points $(P<0.05, r=0.3-0.5)$ were observed after exposure of $4 \mathrm{~Gy}$ radiation dose. In $5 \mathrm{~Gy}$ radiation dose group, significant differences were observed from 2 to $72 \mathrm{~h}$ post radiation exposure $(P=0.002, r=0.481)$. It was evident that median value difference of control and post radiation BALF sample showed high significance. Post hoc comparison revealed that the effect size of difference increased with the time.

Lymphocyte and Neutrophils. Significant change in lymphocyte level in all radiation groups $(P<0.01)$ except at 3 Gy exposure $(P=0.04)$ were observed. Post hoc test revealed significant change after $2 \mathrm{~h}(P=0.002, r=0.482)$ at $1 \mathrm{~Gy}$ exposure. Significant changes were observed at 24,48 and $72 \mathrm{~h}$ post radiation exposure of $2 \mathrm{~Gy}(P<0.02, r=0.3-$ $0.5)$. Lymphocyte level was significantly altered at 24,48 and $72 \mathrm{~h}$ post exposure of 5Gy $(P<0.009)$. Similar trend was observed in BALF neutrophils level in all groups except in 3Gy radiation exposure, where less significant changes were observed $(P=0.03)$. Post hoc test revealed that changes were found significant at 48 and $72 \mathrm{~h}(P=0.041,0.02$ and $r=0.335,0.483)$. It was observed that level of lymphocytes and neutrophils were significantly changed at all time points in 1Gy-5Gy radiation exposure which was confirmed by post hoc analysis.

Total leukocyte count (TLC). In addition, significant changes of total leukocyte count were 

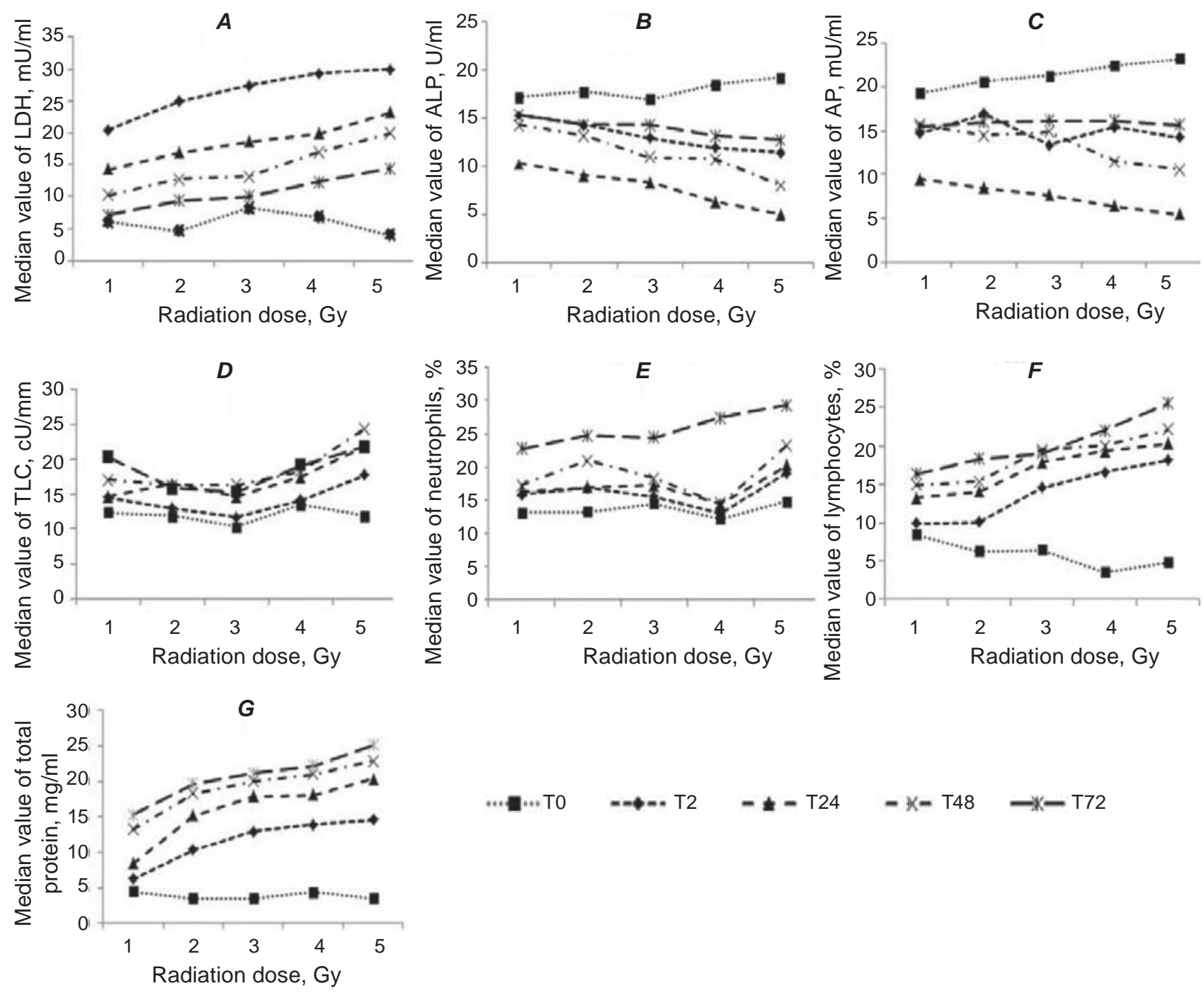

Fig. 1. Effect of $1 G y$ to $5 G y$ radiation dose on BALF parameter at different radiation dose: $A-$ lactate dehydrogenase (LDH); B - alkaline phosphatase (ALP); C-acid phosphatase (AP); D - total leukocyte count (TLC); E-neutrophils; F-lymphocytes; G-total protein. Whereas, T0 (control BALF sample), T2 (post radiation 2 h sample), T24 (post radiation 24 h sample), T48 (post radiation 48 h sample), T72 (post radiation 72 h sample)

observed in radiation group 2Gy-5Gy, except 1Gy group. It was found significant in $3 \mathrm{~Gy}-5 \mathrm{~Gy}$ radiation exposure groups $(P<0.05)$. Post hoc test revealed significant change at $3 \mathrm{~Gy}$ at 24 and $48 \mathrm{~h}$ post exposure $(P=0.026,0.004)$ with medium effect size $(r=0.364,0.450)$, while at 5 Gy radiation exposure, significant changes at 24 and $72 \mathrm{~h}$ post exposure $(P=0.041,0.002, r=0.337,0.489)$. The differences of median value of TLC were found highly significant at each time point except $2 \mathrm{~h}$ in 1Gy to 5Gy radiation dose which was later confirmed by post hoc analysis.
BALF collection is a minimally invasive procedure that offers advantage in studying the lung diseases due to heterogeneous cellular population which makes it valuable tool for studying immune and inflammatory mechanisms in pulmonary disorders $[15,16]$. There have been only a few studies to measure the radiation induced lung injury in BALF. The LDH activity in BALF was observed as high in the animals of irradiated group compared to the control group. No significant differences were observed in ALP \& AP activity in BALF at low radiation doses. The protein concentration an indicator 
of vascular permeability, reached at maximum at $72 \mathrm{~h}$ after 1Gy-5Gy radiation exposure (Fig. 1). High radiation dose resulted in damage to pneumocytes and endothelial cells thus increasing vascular permeability.

Cellular profile of BAL fluid. The radiation exposure results in the damage of pneumocytes and endothelial cells. Inflammatory mediators released from injured alveolar and interstitial cell cause inflammation and in return they increase vascular permeability [17-18]. Furthermore, the alveolar space is filled with exudates due to direct radiation injury and inflammatory process. In addition to their defensive role, lymphocytes and neutrophils are associated with pathophysiological process of radiation induced injury [19-20]. Alveolar inflammation is indicated by elevated levels of neutrophil. Hematopoietic stem cells (HSCs) initiate the production of neutrophil in bone marrow. Generally the major portion of mature neutrophils remains in bone marrow and only $2 \%$ of them are released into blood stream with circulation time of $10-24 \mathrm{~h}$ and after that they migrate into surrounding tissues [21]. Due to ionizing radiation induced inflammation, lung cells secrete potent inflammatory mediators and neutrophil chemo-attractants [22]. This activation mediates the release of neutrophils from the circulation by migration across the vascular endothelium to the site of inflammation. A marked difference of cellular profile in radiation exposed BALF samples of patients with lung cancer treated with radiotherapy showed activation of inflammatory cells, in which lymphocyte level increased after radiotherapy. Yi et al. reported the altered level of inflammatory cells in BALF from irradiated lungs [23]. In the present study (Fig. 2), the proportion of lymphocytes was increased at higher dose (2Gy-5Gy), while the proportion of neutrophils did not alter significantly in irradiated lung at lower doses. The maximum amount of inflammatory cells in BALF was seen at 48-72 $\mathrm{h}$ after 3Gy-5Gy of post radiation exposure.

Lactate dehydrogenase activity in BALF. The enzyme activity in BALF may provide a quantitative assessment of cell damage and pulmonary defence mechanisms. Inflammatory response is not only reflected by the amount of cells involved in the process, but it is also reflected by release of inflammatory mediators or enzymes indicating cell death such as LDH and ALP [24]. In the present study, the cellular profile as well as the LDH activity was changed significantly in gamma irradiated animals in comparison to control. Salovaky reported the gamma radiation induced changes in LDH level [25]. Radiation exposed animals showed high LDH levels after $2 \mathrm{~h}$ post radiation exposure and then started decreasing till $72 \mathrm{~h}$. Dose response between radiation dose and time is shown in Fig. 1.

Alkaline phosphatase in BALF. Type II pneumocytes play an important role in the repair of damaged alveolar epithelial cell due to injury and oxidative stress. Normally, type II cells are not present in BALF. The ALP activity, a marker of type II cell damage and/or proliferation was reported to be changed in BALF after gamma radiation exposure. In the present study, the BALF samples showed a low ALP activity in radiation exposed groups at higher dose in comparison to low radiation dose. However, no significant difference in ALP activity was recorded between BALF samples of radiation treated and control group. As a result, ALP activity, in contrast to LDH could not differentiate between the animals of control and irradiated group.

Acid phosphatase in BALF. The acid phosphatase is secreted from activated or damaged phagocytizing cells (polymorphonuclear and/or alveolar macrophages) and enters into Bronchoalveolar spaces. No significant change was observed in acid phosphatase level after single exposure of whole body gamma radiation. The trend of altered level of ALP and AP was found towards an achievement of control values on the $3^{\text {rd }}$ day after 1Gy-5Gy dose exposure. It can be accepted as an evidence for a functional state recovery of the damaged lung cells in the later. Gamma radiation exposure results in increase in microvasculature permeability, which causes an excessive leakage of plasma protein onto the alveolar surfaces. However, in the present study the protein concentration in BALF from the irradiated animal peaked at $72 \mathrm{~h}$ after 5Gy of radiation exposure.

Advantage of enzyme activity measurement in BALF. The quantification of enzymatic markers of inflammation and cell damage, such as ALP, LDH and AP appeared to be valuable to identify the role of inflammatory cells involved in the pathologic process. At the time of nuclear event, if it is not possible to assess the total cell count, monitoring of biochemical changes may help to establish the inflammatory cell status of a radiation exposed victim. It has been observed that the cell counting varies due to inter-observant differences; while on the other hand the measurement of enzymatic activity is well established and standardized [26]. Measurements of 

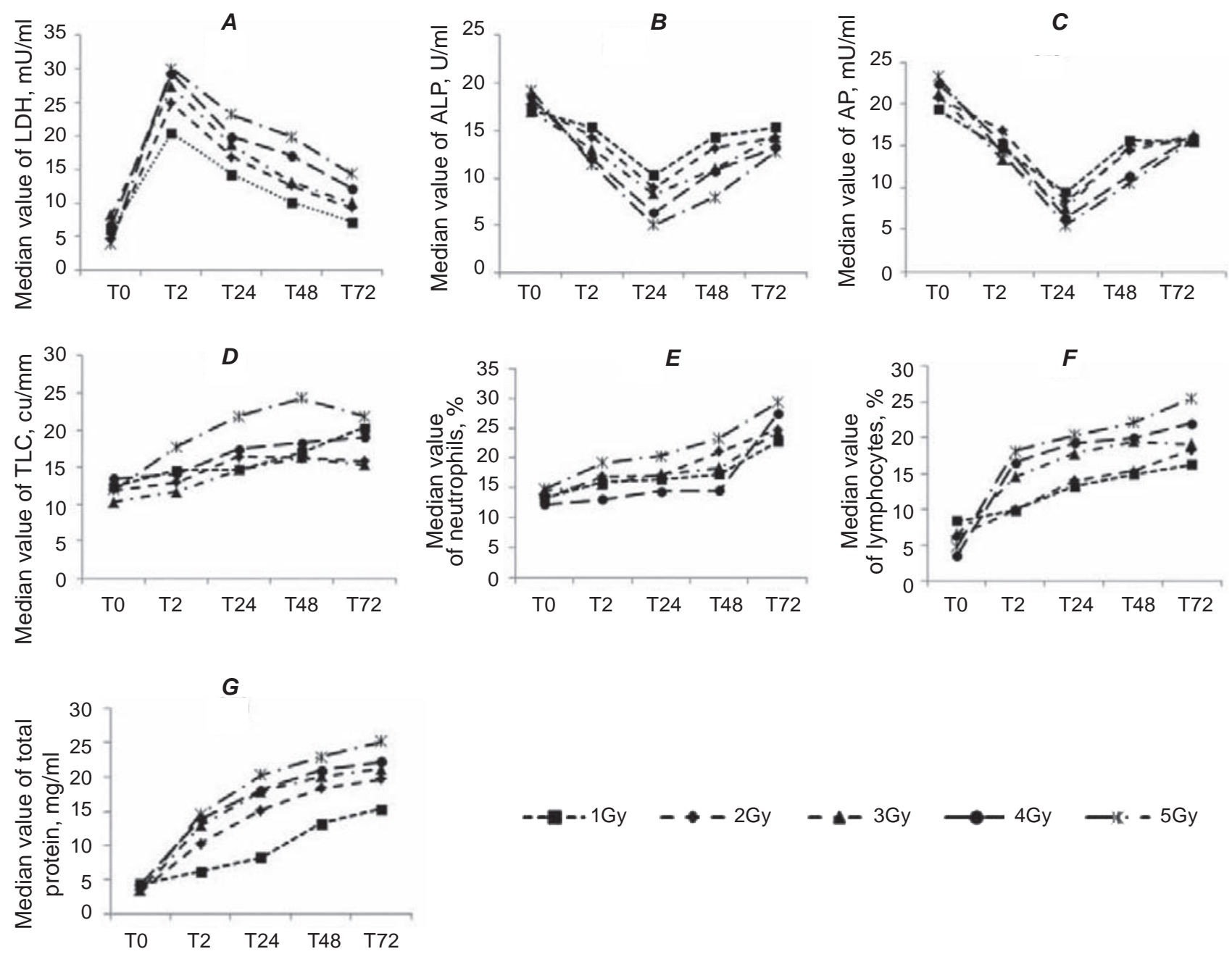

Fig. 2. Effect of $1 G y$ to $5 G y$ radiation dose on BALF parameter at different time intervals: A - lactate dehydrogenase (LDH); $B$ - alkaline phosphatase (ALP); $C$-acid phosphatase (AP); D - total leukocyte count (TLC); E-neutrophils; F-lymphocytes; G-total protein. Whereas, T0 (control BALF sample), T2 (post radiation $2 \mathrm{~h}$ sample), T24 (post radiation $24 \mathrm{~h}$ sample), T48 (post radiation $48 \mathrm{~h}$ sample), T72 (post radiation 72 h sample)

LDH, ALP and AP levels can be done within $2 \mathrm{~h}$ time period (Fig. 2. A, $B$ and $C$ ). So, in the case of nuclear accidents, their level can be measured without delay at any hospital. The present study has some limitations. BAL was performed in different rats at different times. The individual variation between rats might influence the power of statistical significance.

In conclusion, the measurement of the cellular profile as well as the estimation of biochemical changes in BALF has an additional value for the differentiation of radiation exposed victims from unexposed persons. In particular, TLC, total protein and the percentage of lymphocytes in BALF demonstrated significant changes which helps in calculation of radiation dose received by exposed animals. Further studies are required to support the clinical relevance of cellular profile and biochemical analysis for the triage of radiation exposed individuals. Many of the problems in emergency scenario might be overcome by using multi-parameteric approach (for example, using screening markers and confirmation markers). BALF parameters combined with cytogenetic assays can provide valuable information in dose estimation for better triage.

Acknowledgment: The authors are thankful to Indian Council for Medical Research (ICMR: grant no: 3/2/2/163/2012/NCD-III), for providing necessary funding for the work. 
Data on financial support: Financial support by Indian council of medical research (3/2/2/163/2012/ NCD-III).

Conflicts of interest: There is no conflict of interest with any other person or organization for publication of this research article.

\section{РІЗНІ ПАРАМЕТРИЧНІ ПІДХОДИ 3 МЕТОЮ ОЦІНЮВАННЯ ГОСТРОГО ПРОМЕНЕВОГО УРАЖЕННЯ ЛЕГЕНІВ У ЩУРІВ}

\author{
Sandeep Soni ${ }^{1}$, Mitra Basu ${ }^{2}$, Priyanka \\ Agrawal $^{2}$, Neeraj Kumar', Aseem Bhatnagar ${ }^{2}$, \\ Neelam Chhillar ${ }^{1}$ \\ ${ }^{1}$ Institute of Human Behaviour and Allied \\ Sciences, Dilshad Garden, India; \\ e-mail: nlmchhillar@yahoo.co.in; \\ ${ }^{2}$ Institute of Nuclear Medicine and Allied Sciences \\ (INMAS), Defence Research \& Development \\ Organization (DRDO), Delhi, India
}

Вивчали ефект одноразового загального $\gamma$-опромінення і його вплив на секрецію різних клітинних компонентів, які можуть бути використані як біохімічні маркери пошкодження легенів $з$ метою оцінювання гострого променевого ураження легенів. Дослідження проводили на щурах, яких опромінювали в дозі від 1 до 5 Гр (зі швидкістю - 0,95 Гр/хв). Бронхоальвеолярний лаваж (БАЛ) отримували від тварин контрольної та дослідних груп (впродовж 72 год після опромінення). У рідинах БАЛ аналізували активність лактатдегідрогенази (ЛД), кислої фосфатази (КФ), лужної фосфатази (ЛФ), також робили підрахунок клітин i вимірювали загальний вміст протеїну. Внутрішньогрупове і міжгрупове порівняння параметрів БАЛ за різних доз опромінення продемонструвало значну відмінність. Так, активність ЛД в інтервалі опромінення від 1 до 5 Гр $(P=0,00)$ значно збільшувалась після 2 год опромінення з різницею $r>0,3$. Активність ЛФ значно змінилась після опромінення дозами 3 і 4 Гр $(P<0,05)$, тоді як КФ - в інтервалі $2-5$ Гр $(P<0,05)$. Загальний вміст протеїну також істотно змінився в досліджуваному інтервалі опромінення $(P<0,00)$. Таким чином, дослідження БАЛ щурів після одноразового $\gamma$-опромінення показало, що ЛД, КФ, ЛФ, нейтрофіли, лімфоцити, загальна кількість лейкоцитів і загальний вміст протеїну чутливі до пошкоджуючого опромінювання і біохімічні показники їх істотно змінюються впродовж 72 год дослідження. Дійшли висновку, що біохімічні показники БАЛ можуть мати більш широке застосування у разі оцінки гострого ураження легенів за індукованого опромінення.

Ключов і слова: гостре радіаційне ураження легенів, бронхоальвеолярний лаваж (БАЛ), біохімічні показники.

\section{РАЗЛИЧНЫЕ ПАРАМЕТРИЧЕСКИЕ ПОДХОДЫ ДЛЯ ОЦЕНКИ ОСТРОГО ЛУЧЕВОГО ПОРАЖЕНИЯ ЛЕГКИХ У КРЫС}

Sandeep Soni ${ }^{1}$, Mitra Basu ${ }^{2}$, Priyanka Agrawal $^{2}$, Neeraj Kumar ${ }^{2}$, Aseem Bhatnagar ${ }^{2}$, Neelam Chhillar ${ }^{1}$

${ }^{1}$ Institute of Human Behaviour and Allied Sciences, Dilshad Garden, India; e-mail: nlmchhillar@yahoo.co.in;

${ }^{2}$ Institute of Nuclear Medicine and Allied Sciences

(INMAS), Defence Research \& Development Organization (DRDO), Delhi, India

Изучали эффект однократного общего $\gamma$-облучения и его влияние на секрецию различных клеточных компонентов, которые могут быть использованы как биохимические маркеры для оценки острого лучевого поражения легких. Исследования проводили на крысах, которых облучали в дозе от 1 до 5 Гр (со скоростью 0,95 Гр/мин). Бронхоальвеолярный лаваж (БАЛ) получали от животных контрольной и опытных групп (в течении 72 ч после облучения). В жидкостях БАЛ анализировали активность лактатдегидрогеназы (ЛД), кислой фосфатазы (КФ), щелочной фосфатазы (ЩФ), также проводили подсчет клеток и измеряли общее содержание протеина. Внутригрупповые и межгрупповые сравнения параметров БАЛ при различных дозах облучения продемонстрировало значительные различия. Так, активность ЛД в интервале доз облучения от 1 до 5 Гр $(P=0,00)$ значительно увеличивалась после 2 ч облучения с разницей $r>0,3$. Активность ЛФ значительно изменилась после облучения дозами 3 и 4 Гр $(P<0,05)$, тогда как КФ - в интервале $2-5$ Гр $(P<0,05)$. Общий уровень протеина также существенно изменился в исследуемом интервале облучения $(P<0,00)$. Таким образом, исследования БАЛ после одно- 
кратного общего $\gamma$-облучения крыс показало, что активность ЛД, КФ, ЩФ, нейтрофилы, лимфоциты, общее количество лейкоцитов и общее содержание протеина чувствительны к облучению и их биохимические показатели существенно изменяются в течение 72 часов исследования. Сделан вывод, что биохимические показатели БАЛ могут иметь более широкое применение для оценки острого лучевого поражения легких при индуцированном облучении.

Ключевые слова: острое радиационное поражение легких, бронхоальвеолярный лаваж (БАЛ), биохимические показатели.

\section{References}

1. Ramesh A. C., Kumar S. Triage, monitoring and treatment of mass casualty events involving chemical, biological, radiological, or nuclear agents. J. Pharm. Bioallied. Sci. 2010; 2(3): 239247.

2. Rea M. E., Gougelet R. M., Nicolalde R. J., Geiling J. A., Swartz H. M. Proposed triage categories for large-scale radiation incidents using high-accuracy biodosimetry methods. Health Phys. 2010; 98(2): 136-144.

3. Blakely W. F., Salter C. A., Prasanna P. G. S. Earlyresponse biological dosimetryrecommended countermeasure enhancements for masscasualty radiological incidents and terrorism. Health Phys. 2005; 89(5): 494-504.

4. Takavar A., Minaei B., Hadadi G. H., Khoei S., Refahi S., Behrouzkia Z., Pourissa M., Ghama$\mathrm{mi}$ G. Late histopathological findings in the thoracic irradiation: A preliminary study in the animal model. Life Sci. J. 2013; 10(7s): 583-585.

5. Stone H. B., Coleman C. N., Anscher M. S., McBride W. H. Effects of radiation on normal tissue: consequences and mechanisms. Lancet Oncol. 2003; 4(9): 529-536.

6. Mansoub N. H. Influence of Cobalt(60) radiation on the Rat Lung. Ann. Biol. Res. 2011; 2(5): 563566.

7. Ataya S., Elwing J., Biddinger P., Panos R. J. Radiation induced lung injury. Clin. Pulm. Med. 2006; 13(4): 232-242.

8. King T. E. The handling and analysis of bronchoalveolar lavage specimens. Mosby Book, St. Louis, Mo 1992.

9. Henderson R. F. Analysis of respiratory tract lining fluids to detect injury. CRC Press Inc., 1991.
10. Linder J. and Rennard S. I. Broncho-alveolar lavage. American Society of Clinical Pathologists Press. Chicago, 1988.

11. Henderson R. F., Scott G. G., Waide J. J. Source of alkaline phosphatase activity in epithelial lining fluid of normal and injured F344 rat lungs. Toxicol. Appl. Pharmacol. 1995; 134(1): 170-174.

12. Revised guide for the care and use of laboratory animals. NIH guide. 1996, 25;28.

13. Henderson R. F., Benson J. M., Hahn F. F., Hobbs C. H., Jones R. K., Mauderly J. L., McClellan R. O., Pickrell J. A. New approaches for the evaluation of pulmonary toxicity: bronchoalveolar lavage fluid analysis. Fundam. Appl. Toxicol. 1985; 5(3): 451-458.

14. Sole P. D., Pagliari G., Napolitano M., Frigeri L., Delia C., Anna M., Marzo A. D., Valentini S., D'Onofrio G. Cell count in bronchoalveolar lavage fluid: comparison between counting chamber and two automatic cell counters. $J$. Bronchology Interv. Pulmonol. 1996; 3(3): 192195.

15. Reynolds H. Y. Use of bronchoalveolar lavage in humans-past necessity and future imperative. Lung. 2000; 178(5): 271-293.

16. Costabel U., Guzman J. Bronchoalveolar lavage in interstitial lung disease. Curr. Opin. Pulm. Med. 2001; 7(5): 255-261.

17. Chen Y, Williams J, Ding I, Hernady E, Liu W, Smudzin T, Finkelstein JN, Rubin P, Okunieff P. Radiation pneumonitis and early circulatory cytokine markers. Semin. Radiat. Oncol. 2002; 12(1 Suppl 1): 26-33.

18. Hong J. H., Jung S. M., Tsao T. C., Wu C. J., Lee C. Y., Chen F. H., Hsu C. H., McBride W. H., Chiang C. S. Bronchoalveolar lavage and interstitial cells have different roles in radiationinduced lung injury. Int. J. Radiat. Biol. 2003; 79(3): 159-167.

19. Park K. J., Oh Y. T., Kil W. J., Park W., Kang S. H., Chun M. Bronchoalveolar lavage findings of radiation induced lung damage in rats. J. Radiat. Res. 2009; 50(3): 177-182.

20. Nakayama Y., Makino S., Fukuda Y., Min K. Y., Shimizu A., Ohsawa N. Activation of lavage lymphocytes in lung injuries caused by radiotherapy for lung cancer. Int. J. Radiat. Oncol. Biol. Phys. 1996; 34(2): 459-467.

21. Von Vietinghoff S., Ley K. Homeostatic regulation of blood neutrophil counts. J. Immunol. 2008; 181(8): 5183-5188. 
22. Sadik C. D., Kim N. D., Luster A. D. Neutrophils cascading their way to inflammation. Trends Immunol. 2011; 32(10): 452-460.

23. Yi E. S., Bedoya A., Lee H., Chin E., Saunders W., Kim S. J., Danielpour D., Remick D. G., Yin S., Ulich T. R. Radiation-induced lung injury in vivo: expression of transforming growth factorbeta precedes fibrosis. Inflammation. 1996; 20(4): 339-352.

24. Henderson R. F. Use of bronchoalveolar lavage to detect lung damage. Environ. Health Perspect. 1984; 56: 115-129.
25. Salovsky P., Shopova V., Dancheva V., Marev R., Pandurska A. Enhancement of the pneumotoxic effect of cadmium acetate by ionizing radiation in the rat. Environ. Health Perspect. 1993; 101(Suppl 2): 269-274.

26. Kleyklamp B. O., Baughman R. P. Who should perform broncho-alveolar lavage analysis? Am. J. Respir. Crit. Care. Med. 1998; 157: 167.

Received 23.09.2015 